\title{
CONTRIBUTION OF GROUND WATER TABLE ON MAIZE YIELD AND IRRIGATION REQUIREMENTS IN NORTH NILE DELTA
}

\author{
Eid, S. M. ; A. A. EL- Araby ; A. A. S. Gendy and H. A. Khafagy \\ Soils, Water and Environment Research Institute, A.R.C., Giza, Egypt
}

\begin{abstract}
Due to the increasing demand of food by its ever-increasing population, the pressure on fresh water resources of Egypt is increasing. Optimum utilization of surface and groundwater resources has become extremely important to fill the gap between water demand and supply. Maize (Zea maize L.) of hybrid single cross 10 plant was grown in two field experiments to investigate the effect of irrigation depth and irrigation intervals on contribution of water table and yield of maize crop during 2009and 2010 at Sakha region, Kafr El Sheikh Governorate The site represents the circumstances and conditions of Middle North Nile Delta region and allocated at 31 07' N Latitude, 30-57'E Longitude with an elevation of about 6 metres above mean sea level. Main plots were assigned to depth of irrigation (A) depth $5 \mathrm{~cm}=210 \mathrm{~m}^{3}$ /fed. , (B) depth $7 \mathrm{~cm}=294 \mathrm{~m}^{3} / \mathrm{fed}$. and (C)Depth $9 \mathrm{~cm}=378 \mathrm{~m}^{3} / \mathrm{fed}$. (each irrigation), while subplots were irrigated with irrigation intervals i.e. 10, 15 and 20 days, (1, 2 and 3 respectively) .

Results showed that SMD was not affected by depth of irrigation applied, but a clear effect was observed from the irrigation intervals. Seasonal SMD values in the first season are $52.0,67.9$ and $83.9 \mathrm{~cm}$ for $A_{1}, B_{1}$ and $C_{1}$, respectively .In the second season, the corresponding values of the same treatments are $53.0,68.9$ and $84.9 \mathrm{~cm}$ respectively. for treatment $A_{1}, A_{2}$ and $A_{3}$ which represent the effect of irrigation intervals, values are $52.0,37.0$ and $32.0 \mathrm{~cm}$ respectively in the first season. While the corresponding values in the second season are 53.0,38.0 and $33.0 \mathrm{~cm}$ respectively.

Fluctuation of water table level, it was observed, that the depth of water table reached the lowest value immediately before irrigation. While the maximum water depth reached at 2 days after irrigation. Contribution of ground water table to $\mathrm{ET}_{\mathrm{c}}$ was found to be depended on growth stage and both of depth and intervals of irrigation. Data also showed that with increasing irrigation intervals, the contribution increased also from 8.4 to 20.6 to $40.8 \%$ for $A_{1}, A_{2}$ and $A_{3}$ treatments, respectively. Under the same irrigation interval of 20 days which accompanied with increase in water depth applied from 5 to 7 to $9 \mathrm{~cm}$ i.e. treatments $A_{3}, B_{3}$ and $C_{3}$ the contribution of water table decreased from 40.8 to 14.6 to $10.5 \%$, respectively.

Keywords: Water management, Drainage practices, Contribution of groundwater table, Maize
\end{abstract}

\section{INTRODUCTION}

Irrigation and drainage systems are usually considered separately without regard for interactions between the water table and the soil root zone (with the exception of leaching and deep percolation losses). Irrigation scheduling assumes that the soil is adequately drained, either naturally or artificially, and that irrigation should begin when soil moisture is depleted to a given point. Artificial drainage systems, mostly tiling, are designed to lower the water table sufficiently to minimize its damage to crops from water logging 


\section{Eid, S. M. et al.}

or salinization of the root zone. Incorporating the potential contribution of shallow water table into irrigation-drainage system design requires knowledge of the volume and salinity of water available to crops at different water table depths. Knowing the size of the water reservoir available for crop use may make it possible to reduce irrigation frequency during the growing season. The shallow water table, however, must be replenished periodically. In addition to the labor and cost savings in reducing irrigation frequency, costs can be lowered by installing drainage tile systems at shallower depths or wider spacing than are normally used. Successful use of the water table also depends on the water retention of soil and transmitting properties, evapotranspiration (ET) demand, distribution of the plant root system, and salinity and toxic ion effects on crop growth. Under field conditions, many of these factors are part of the overall crop response to the saline high water table.

Shallow water tables are a common feature of many irrigation areas due to high recharge rates and, frequently, reduced drainage rates once groundwater is in close proximity to the ground surface, capillary up flow results in the movement of water and salts towards the soil surface potentially leading to salt accumulation in the root zone. Soil Stalinization above the water table is therefore affected by capillary up flow, groundwater position, groundwater salinity and soil and crop characteristics (Soppe and Ayars, (2003); Hutmacher et al., (1996) and King et al., (1995).

Shallow ground water table exists in many areas of the world. This shallow ground water can be used by plants either by using drainage water for irrigation or through in situ use. Saline drainage ground water has been studied extensively as a supplemental source of irrigation water (Rhoades et al.,(1989);Ayars et al., (1993), (2006). In situ use of ground water by crops is a more complicated matter than irrigating with drainage ground water. It depends on several factors such as depth to the water table, hydraulic properties of the soil, stage of the crop growth, ground water quality etc. Quantification of the water taken by the roots from the shallow water table is of great significance and has been a topic of extensive research in the last few decades. Ayars and Schoneman (1986) found that capillary rise of water of $E C e=10 \mathrm{dSm}^{-1}$ from a water table of $1.7-2.1 \mathrm{~m}$ deep contributed to up to $37 \%$ of evapotranspiration (ET) of a cotton crop Irrigated. Kahlown et al. (2005) investigated the effect of shallow water tables on crop water requirements by using 18 large size drainage type concrete lysimeters.

They found that when a water table was kept at a depth of $0.5 \mathrm{~m}$, wheat met its entire water requirement from the ground water. Sunflower required only $20 \%$ of its total need from irrigation. The gap between water demand and supply has increased manifolds, due to increased agricultural activities and reduced river flows. Availability of adequate good quality water is one of the most important inputs in successful crop production. Distribution of water among the canals in Egypt is generally based on historical allocations and does not consider crop water requirements, water-table depth, and soil physico-chemical conditions. About a century ago, water 
allowances were fixed for different canals depending upon the surface water availability and the area to be covered. Since then many changes have taken place. Due to seepage from the irrigation network and non-functional drainage systems, water table in many areas had risen to near the soil surface.

Groundwater is a flexible and reliable source of water. However, excessive pumping by deep public and private tube wells is often pulling up water with substantial salinity and is causing secondary soil salinization, whereas shallow fresh groundwater is not utilized. Therefore, there is a need for more judicious use of this precious water. Shallow groundwater could also be used as sub-irrigation by adopting proper irrigation scheduling to help bridge the gap between water demand and supply. Pratharpar and Qureshi (1998) observed that in areas where shallow water tables exist, the irrigation requirements can be reduced to $80 \%$ of the total crop ET without reducing crop yield and increasing soil salinization. This practice not only produced good yields but also kept the soil salinity and water-table depth within the acceptable limits. (Ahmed (1992) reported the findings of the various studies on growing wheat and maize on raised beds, broad beds and ridges at different sites of Pakistan. Wheat performed better on raised bed of $95 \mathrm{~cm}$ width under $0.6 \mathrm{~m}$ water table depth from ground surface.

The increase in wheat yield was 30 to 35 percent and water saving was 30 to 40 percent compared to flat basin planting. Wheat yield was higher on flat basin under water table depth beyond $0.6 \mathrm{~m}$. Maize also performed well when planted on broad beds of $105 \mathrm{~cm}$ width or ridges (irrigation to every furrow or to alternate furrow) under water table depth of $1 \mathrm{~m}$ below soil surface. The main conclusion was that under high water table conditions, crop bed planting would result in reduced seasonal irrigation requirements and consequently reduced drainage surplus.

The main objectives of this study were to determine

(i) The irrigation requirements and evapotranspiration of maize crop under shallow water-table depths,

(ii) Groundwater contribution to the crop water requirement under shallow water-table depth,

(iii) Effect of shallow water table-depth on crop yields.

\section{MATERIALS AND METHODS}

A field trial was conducted during the two successive growing seasons 2009 and 2010 at Sakha Agricultural Research Station, Kafr EL-Shiekh Governorate. The site represents the circumstances and conditions of Middle North Nile Delta region and allocated at 31-07' N Latitude, 30-57'E Longitude with an elevation of about 6 metres above mean sea level. Soil of the experimental field is clayey in texture as shown in Table (1). All agricultural practices were the same as executing in the area except the tested treatments. 
Eid, S. M. et al.

Table (1): Mean of some meteorological data for Sakha area during the two growing seasons of Maize crop

\begin{tabular}{|c|c|c|c|c|c|c|c|c|c|c|c|c|c|c|}
\hline & \multicolumn{7}{|c|}{ Season 2009} & \multicolumn{7}{|c|}{ Season 2010} \\
\hline & \multicolumn{2}{|c|}{$\begin{array}{c}\text { Air } \\
\text { Temp.C }\end{array}$} & \multicolumn{2}{|c|}{$\begin{array}{c}\text { Relative } \\
\text { humidity, } \%\end{array}$} & \multirow{2}{*}{ 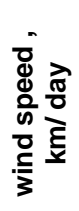 } & \multirow{2}{*}{$\begin{array}{l}\text { Ep, } \\
\text { mm/ } \\
\text { day }\end{array}$} & \multirow{2}{*}{ : } & \multicolumn{2}{|c|}{$\begin{array}{c}\text { Air } \\
\text { Temp. } \mathbf{C}^{\circ}\end{array}$} & \multicolumn{2}{|c|}{$\begin{array}{c}\text { Relative } \\
\text { humidity, } \\
\%\end{array}$} & \multirow{2}{*}{ 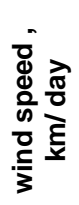 } & \multirow{2}{*}{$\begin{array}{l}\text { ते } \\
\text { ô } \\
\text { E } \\
\text { E } \\
\text { i̊ }\end{array}$} & \multirow{2}{*}{ 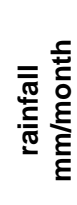 } \\
\hline & maxi. & $\min$. & $\max$ & $\min$ & & & & $\max$ & $\min$ & $\max$ & $\min$ & & & \\
\hline Jul. & 33.0 & 20.2 & 80.0 & 50.0 & 94.0 & 7.26 & ---- & 32.0 & 20.0 & 82.0 & 48.2 & 102.0 & 7.21 & ----- \\
\hline Aug. & 32.4 & 19.0 & 81.50 & 51.0 & 77.0 & 6.60 & ---- & 34.0 & 21.2 & 85.0 & 50.8 & 93.5 & 6.80 & ----- \\
\hline Sep. & 32.5 & 19.0 & 77.0 & 46.0 & 83.0 & 6.35 & ---- & 33.4 & 19.2 & 82.2 & 48.5 & 88.0 & 5.5 & |------ \\
\hline Oct. & 30.3 & 16.2 & 75.5 & 48.0 & 62.0 & 4.25 & ---- & 30.7 & 17.0 & 72.0 & 45.0 & 73.0 & 4.01 & ---- \\
\hline
\end{tabular}

Table (2):Some soil physical and chemical properties of the experimental site

\begin{tabular}{|l|c|c|c|c|c|c|c|c|c|}
\hline \multirow{2}{*}{ Depth } & \multicolumn{2}{|c|}{ Particle size distribution } & \multirow{2}{*}{ Texture } & \multirow{2}{*}{$\begin{array}{c}\text { F.C } \\
\text { W\% }\end{array}$} & \multirow{2}{*}{$\begin{array}{l}\text { PWP } \\
\text { W\% }\end{array}$} & $\begin{array}{c}\text { Bulk } \\
\text { density } \\
\text { g/cm }\end{array}$ & \multicolumn{2}{|c|}{$\begin{array}{c}\text { Available } \\
\text { water }\end{array}$} \\
\cline { 2 - 7 } & Sand\% & Silt\% & Clay\% & & & & & w\% & mm \\
\hline $\mathbf{0 - 1 5}$ & 15.28 & 18.80 & 65.92 & Clayey & 47.2 & 25.65 & 1.14 & 21.55 & 36.8 \\
$\mathbf{1 5 - 3 0}$ & 19.90 & 13.80 & 66.30 & Clayey & 40.5 & 22.01 & 1.15 & 18.45 & 31.8 \\
$\mathbf{3 0 - 4 5}$ & 16.59 & 16.92 & 66.49 & Clayey & 37.0 & 20.10 & 1.24 & 16.91 & 31.4 \\
$\mathbf{4 5 - 6 0}$ & 17.65 & 15.24 & 67.12 & Clayey & 34.5 & 18.79 & 1.26 & 15.71 & 29.6 \\
\hline
\end{tabular}

\section{Experimental layout.}

All agronomic practices were the same as recommended for the studied area, except the two study factors which i.e. depth of irrigation and irrigation interval. The plot area was $52.5 \mathrm{~m}^{2}$, the distance between ridges was $70 \mathrm{~cm}$ and the seeds were sown at $25 \mathrm{~cm}$ between hills within the ridge. Maize (Zea maize L.) of hybrid single cross 10 was sown at 1 and 3 July in 2009 and 2010 respectively. Dates of harvesting were Oct., 24,2009and Oct., 26, 2010.The treatment were as flow: Main treatment (depth of irrigation),(A)Depth $5 \mathrm{~cm}=210 \mathrm{~m}^{3} / \mathrm{fed}$. (each irrigation),(B)Depth $7 \mathrm{~cm}=294$ $\mathrm{m}^{3}$ /fed. (each irrigation),(C)Depth $9 \mathrm{~cm}=378 \mathrm{~m}^{3} / \mathrm{fed}$. (each irrigation). Sub treatment ( irrigation intervals):1-Irrigation every 10 days,2-Irrigation every 15 days,3-Irrigation every 20 days.

\section{Data collection}

Irrigation water:

Irrigation water was controlled and measured by a fixed rectangular weir, $30 \mathrm{~cm}$ base width with discharge $0.01654 \mathrm{~m}^{3} / \mathrm{sec}$ at $10 \mathrm{~cm}$ as effective head.

Water applied (Wa):

Water applied (Wa) was calculated as, Giriapa (1983):

$\mathrm{Wa}=\mathrm{Iw}+\mathrm{Re}+\mathrm{S}$

where:

Iw = irrigation water applied

$\mathrm{Re}=$ effective rainfall 
$S=$ amount of soil moisture contributing to consumptive use either from stored

moisture in root zone and / or that from shallow water table.

Soil moisture depletion (SMD):

Soil moisture depletion was calculated using the following equation (Hansen et al., 1979).

$\mathrm{Cu}=\sum_{i=1}^{\mathrm{l}=4} \mathrm{D}_{1} \times \mathrm{D}_{\mathrm{b} 1} \times \frac{\mathrm{PW}_{2}-\mathrm{PW}_{1}}{100}$

$\mathrm{CU}=$ Water consumptive use $(\mathrm{cm})$

$D_{1} \quad=\quad$ Soil layer depth $(15 \mathrm{~cm}$ each $)$.

$D_{b 1}=$ Soil bulk density, $\left(\mathrm{Mg} / \mathrm{m}^{3}\right)$ for this depth.

$\mathrm{PW}_{1}=$ Soil moisture percentage before irrigation (on mass basis, \%).

$\mathrm{PW}_{1}=$ Soil moisture percentage, 48 hours after irrigation (on mass basis, \%).

I = Number of soil layers each $(15 \mathrm{~cm})$ depth

\section{Fluctuation of water table depth:}

In order to establish the diagrams of water table fluctuation during the growing season, nine observation wells were installed along different replicates. Each observation well was twenty two millimetres diameters and two metres depth perforated plastic tube below soil surface, daily reading of water table were recorded

Crop coefficient adjusted for the contribution of the water table $\left(\mathrm{K}_{\mathrm{cw}}\right)$

The crop coefficient $K_{c}$ is generally obtained from the ratio $E T_{c} / E T_{0}$. But under conditions of high water table (the present case), $\mathrm{ET}_{\mathrm{c}}$ cannot directly determined. SMD may be used instead of ETC.

Table (3): Reference evapotranspiration ( $\left.\mathrm{ET}_{0}\right), \mathrm{Kc}(\mathrm{FAO}), \mathrm{ET}_{\mathrm{c}} \mathrm{mm} / \mathrm{day}$ and $\mathrm{ET}_{\mathrm{c}} \mathrm{mm} / \mathrm{month}$

\begin{tabular}{|l|c|c|c|c|}
\hline \multicolumn{1}{|c|}{ Months. } & July. & Aug. & Sept. & Oct. \\
\hline $\mathrm{ET}_{0} \mathrm{~mm} /$ day & 6.92 & 7.46 & 5.45 & 4.29 \\
\hline $\mathrm{Kc}(\mathrm{FAO})$ & 0.15 & 1.2 & 0.6 & 0.35 \\
\hline $\mathrm{ET}_{\mathrm{c}} \mathrm{mm} /$ day & 1.036 & 8.95 & 3.270 & 1.501 \\
\hline $\mathrm{ET}_{\mathrm{c}} \mathrm{mm} / \mathrm{month}$ & 31.14 & 277.51 & 98.10 & 36.02 \\
\hline
\end{tabular}

\section{Contribution of the ground water table (S):}

Water movement by capillary rise from water table into active plant root zone is recognized as an important supplementary water resource for irrigation. The contribution of groundwater as percentage of the consumptive use was calculated as follow:

$\mathbf{S}=\left[\left(\mathrm{ET}_{\mathrm{c}}-\mathrm{SMD}\right)\right.$

Where :

$$
\begin{aligned}
& E T_{c}=\text { Crop evapotranspiration }=\mathrm{ET}_{0} \times \mathrm{K}_{\mathrm{c}} \\
& \mathrm{SMD}=\text { Soil moisture depletion. }
\end{aligned}
$$

Reference evapotranspiration $\left(\mathrm{ET}_{0}\right)$ :

were estimated using penman-Monteith, 
Table (4): Date of irrigation events and Irrigation water applied $\mathrm{m}^{3} / . \mathrm{fed}$ for maize under different irrigation treatments during the two seasons of 2009and2010.

\begin{tabular}{|c|c|c|c|c|c|c|c|c|c|c|c|c|c|c|c|c|c|c|}
\hline \multirow[b]{3}{*}{ Date } & \multicolumn{9}{|c|}{ Season 2009} & \multicolumn{9}{|c|}{ Season 2010} \\
\hline & \multicolumn{3}{|c|}{\begin{tabular}{|l|} 
Depth $5 \mathrm{~cm}$ ) \\
$210 \mathrm{~m}^{3} / \mathrm{fed}$. \\
\end{tabular}} & \multicolumn{3}{|c|}{\begin{tabular}{|l|} 
Depth $7 \mathrm{~cm}$ \\
$294 \mathrm{~m}^{3} / \mathrm{fed}$. \\
\end{tabular}} & \multicolumn{3}{|c|}{\begin{tabular}{|l|} 
Depth $9 \mathrm{~cm}$ \\
$378 \mathrm{~m}^{3} / \mathrm{fed}$. \\
\end{tabular}} & \multicolumn{3}{|c|}{\begin{tabular}{|l|} 
Depth $5 \mathrm{~cm})$ \\
$210 \mathrm{~m}^{3} / \mathrm{fed}$. \\
\end{tabular}} & \multicolumn{3}{|c|}{$\begin{array}{l}\text { Depth } 7 \mathrm{~cm} \\
294 \mathrm{~m}^{3} / \mathrm{fed} .\end{array}$} & \multicolumn{3}{|c|}{$\begin{array}{l}\text { Depth } 9 \mathrm{~cm} \\
378 \mathrm{~m}^{3} / \mathrm{fed} .\end{array}$} \\
\hline & $\begin{array}{l}\stackrel{n}{2} \\
\frac{\pi}{0} \\
0 \\
\end{array}$ & 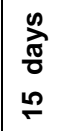 & 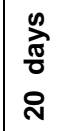 & 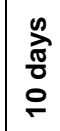 & 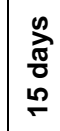 & 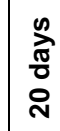 & $\begin{array}{l}\text { n } \\
\text { 정 } \\
\text { 음 }\end{array}$ & $\begin{array}{l}n \\
\underset{\pi}{0} \\
i n \\
n\end{array}$ & 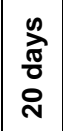 & 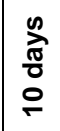 & 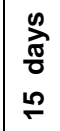 & 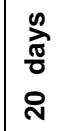 & 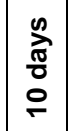 & 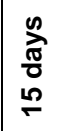 & 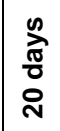 & $\begin{array}{l}n \\
\underset{\pi}{0} \\
0 \\
0\end{array}$ & 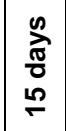 & 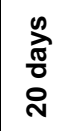 \\
\hline $0 / 6$ & 504 & 504 & 504 & 500 & 500 & 500 & 502 & 502 & 502 & 494 & 494 & 494 & 494 & 494 & 494 & 494 & \begin{tabular}{|l|l}
494 \\
\end{tabular} & \begin{tabular}{|l|}
494 \\
\end{tabular} \\
\hline $0 / 7$ & 210 & 210 & 210 & 294 & 294 & 294 & 378 & 378 & 378 & 210 & 210 & 210 & 294 & 294 & 294 & 378 & 378 & \begin{tabular}{|l}
378 \\
\end{tabular} \\
\hline $30 / 7$ & 210 & & - & 294 & & - & 378 & & - & 210 & & - & 294 & & - & 378 & & \\
\hline $5 / 8$ & & 210 & & & 294 & & & 378 & & & 210 & & & 294 & & & 378 & \\
\hline $10 / 8$ & 210 & 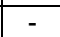 & 210 & 294 & 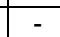 & 294 & 378 & - & 378 & 210 & - & 210 & 294 & - & 294 & 378 & - & \begin{tabular}{|l}
378 \\
\end{tabular} \\
\hline & & & & & & - & & & - & 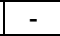 & & - & -1 & & - & - & & - \\
\hline $20 / 8$ & 210 & 210 & - & 294 & 294 & - & 378 & 378 & - & 210 & 210 & - & 294 & 294 & 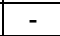 & 378 & 378 & - \\
\hline $30 / 8$ & 210 & & 210 & 294 & & 294 & 378 & & 378 & 210 & & 210 & 294 & & 294 & 378 & & \begin{tabular}{|l|}
378 \\
\end{tabular} \\
\hline $5 / 9$ & & 210 & & & 294 & & & 378 & & & 210 & & & 294 & & & 378 & \\
\hline $10 / 9$ & 210 & - & - & 294 & - & - & 378 & - & - & 210 & 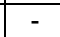 & - & 294 & - & - & 378 & - & - \\
\hline $15 / 9$ & - & & - & - & & 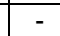 & - & & - & - & & - & - & & - & - & & - \\
\hline $20 / 9$ & 210 & 210 & 210 & 294 & 294 & 294 & 378 & 378 & 378 & 210 & 210 & 210 & 294 & 294 & 294 & 378 & 378 & \begin{tabular}{|l}
378 \\
\end{tabular} \\
\hline $30 / 9$ & 210 & & - & 294 & & 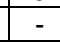 & 378 & & 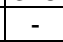 & 210 & & & 294 & & 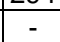 & 378 & & \\
\hline Irrig.no & 9 & 6 & 5 & 9 & 6 & 3 & 9 & 6 & 5 & 9 & 6 & 5 & 9 & 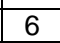 & 5 & 9 & 0 & 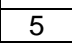 \\
\hline & & & & & & & & & & & & & & & & & & \\
\hline
\end{tabular}

Water productivity (WP):

It was calculated according to (Ali et al., 2007).

WP $=$ GY/ET

Where WP $\left(\mathrm{kg} / \mathrm{m}^{3}\right)$, GY is grain yield $(\mathrm{kg} / \mathrm{fed})$. and ET total water consumption of the growing season $\left(\mathrm{m}^{3} / \mathrm{fed}\right.$.)

Productivity of irrigation water (PIW)

Was calculated as (Ali et al., 2007)

$\mathrm{PIW}=\mathrm{GY} / \mathrm{I}$.

Where I is irrigation water applied $\left(\mathrm{m}^{3} / \mathrm{fed}\right.$.).

\section{Statistical Analysis:}

The obtained data were statistically analyzed by analysis of variance. according to Gomez and Gomez (1984). Means of the treatment were compared by the least significant difference (LSD) at $5 \%$ level of significance which developed by Waller and Duncan (1979)

\section{RESULTS AND DISCUSSION}

\section{Soil moisture depletion (SMD):}

Values of seasonal SMD in $\mathrm{cm}$ are presented in Table (5) for maize as a summer crop under different treatments during the course of study of 2009 and 2010.The obtained data showed that SMD values were greatly affected 
by irrigation intervals. Where SMD values decreased with irrigation intervals. Seasonal values of SMD. during first season were $32 \mathrm{~cm}$ and $83.9 \mathrm{~cm}$ for the driest $\left(A_{3}\right)$ and wettest $\left(C_{1}\right)$. The other treatments were in between. Results of the second season were in the same trend and did not differ greatly. Regards, the effect of water applied on SMD. data should that no clear evidence of irrigation water depth on the values of this trait under fixed irrigation interval. Values of SMD are $52.0,67.9$ and $83.9 \mathrm{~cm}$ during the first season which addressed $A_{1}, B_{1}$ and $C_{1}$ respectively. Values obtained for the second season had also the same trend.

The maximum water depletion value of maize under conditions of the studied area was about $75 \mathrm{~cm}$, then decreased directly with increasing the irrigation intervals. This finding indicated that, in general, to get the maximum soil moisture depletion which consists of water consumed by growing plants and or the water percolated down- ward or upward the water table, irrigation interval should be 10 days under any of the studied water applied 5,7and 9 $\mathrm{cm}$ each irrigation. In other words, the normal irrigation depth of $9 \mathrm{~cm}$ could be minimized to $5 \mathrm{~cm}$ applied each 10 days without any reduction in the value of SMD. This result could be explained by the fact that under the conditions of heavy clay soil and shallow water table of the Nile Delta, the $5 \mathrm{~cm}$ water applied is enough to achieve the highest value of SMD. Under this conditions of maximum SMD. High probability for the feeding of the water table aquifer from the applied irrigation water could be existed. On the other side, the long irrigation intervals of 15 or 20 days the contribution from water table to crop consumptive use may be obtained. This result was in the same direction with those reported by Eid (1994)

Table (5): Seasonal soil moisture depletion SMD in $\mathrm{cm}$ during the two growing seasons of maize crop.

\begin{tabular}{|l|l|c|c|c|c|c|c|}
\hline \multicolumn{2}{|c|}{ Treatment } & \multicolumn{3}{c|}{ Season 2009 } & \multicolumn{3}{c|}{ Season 2010 } \\
\hline \multicolumn{1}{|c|}{ Depth } & interval & No. of irrig. & $\mathbf{c m}$ & $\mathbf{M}^{3}$ & No. of irrig. & $\mathbf{c m}$ & $\mathbf{M}^{\mathbf{3}}$ \\
\hline $\mathbf{A}_{\mathbf{1}}$ & 10days & 9 & 52.0 & 2184.0 & 9 & 53.0 & 2226 \\
$\mathbf{A}_{\mathbf{2}}(\mathbf{5 c m})$ & 15days & 6 & 37.0 & 1554.0 & 6 & 38.0 & 1596 \\
$\mathbf{A}_{\mathbf{3}}$ & 20days & 5 & 32.0 & 1344.0 & 5 & 33.0 & 1386 \\
\hline $\mathbf{B}_{\mathbf{1}}$ & 10 days & 9 & 67.9 & 2851.9 & 9 & 68.9 & 2893.8 \\
$\mathbf{B}_{\mathbf{2}}(\mathbf{7 c m})$ & 15days & 6 & 46.9 & 1969.8 & 6 & 47.9 & 2011.8 \\
$\mathbf{B}_{3}$ & 20days & 5 & 39.9 & 1675.8 & 5 & 40.9 & 1717.8 \\
\hline $\mathbf{C}_{\mathbf{1}}$ & 10days & 9 & 83.9 & 3523.8 & 9 & 84.9 & 3565.8 \\
$\mathbf{C}_{\mathbf{2}}(\mathbf{9 c m})$ & 15days & 6 & 56.9 & 2389.8 & 6 & 57.9 & 2431.8 \\
$\mathbf{C}_{3}$ & 20days & 5 & 45.9 & 1927.8 & 5 & 46.9 & 1969.8 \\
\hline
\end{tabular}

\section{Fluctuation of water table depth during the growing season:}

Seasonal averages of maximum and minimum values of water table depth, for each observation well, under each treatment, during the two growing seasons were given in Table (6). The obtained data showed that the depth of water table reached the highest value immediately before irrigation. While the maximum water depth reached at 2 days after irrigation. Following irrigation, the water table decreased gradually in between irrigation. Lowest values of water table depth varied between $85.3 \mathrm{~cm}$ and $99.9 \mathrm{~cm}$ in the first and second growing seasons. The corresponding values of the minimum 


\section{Eid, S. M. et al.}

water table depth are 45 and $74.8 \mathrm{~cm}$. The fluctuation of the water table depends on the irrigation interval and the distance from the both irrigation canal in the north and main surface drain in the south of the experiment area. The absolute values of both minimum and maximum depth of water table increased directly with increasing irrigation intervals and as much as close to the main open drain in the site. So, by increasing the irrigation intervals, more water being allowed to be depleted by growing plants and consequently further through fall could be obtained. This technique of elongation the irrigation interval in Nile Delta has the advantage of proper aeration in the effective root zone, minimizing the water logging hazard in the area and save a reasonable amount of irrigation water.

Table (6): Maximum, and minimum mean values of the water table depth during the two growing seasons of maize 2009 and 2010

\begin{tabular}{|l|l|c|c|c|c|}
\hline \multirow{2}{*}{$\begin{array}{l}\text { Observation } \\
\text { number }\end{array}$} & well & \multicolumn{2}{|c|}{ Season 2009 } & \multicolumn{2}{|c|}{ Season 2010 } \\
\cline { 2 - 6 } & Treat. & Lowest depth & $\begin{array}{r}\text { Highest } \\
\text { depth }\end{array}$ & Lowest depth & $\begin{array}{c}\text { Highest } \\
\text { depth }\end{array}$ \\
\hline $\mathbf{1}$ & & 45.0 & 87.9 & 45.8 & 85.3 \\
$\mathbf{2}$ & $\mathbf{A}_{\mathbf{1}}$ & 46.6 & 90.7 & 47.6 & 94.9 \\
$\mathbf{3}$ & $\mathbf{B}_{1}$ & 57.4 & 88.7 & 59.4 & 89.7 \\
$\mathbf{4}$ & $\mathbf{C}_{1}$ & 56.8 & 85.9 & 55.8 & 88.9 \\
$\mathbf{5}$ & $\mathbf{A}_{2}$ & 62.7 & 99.9 & 68.7 & 98.9 \\
$\mathbf{6}$ & $\mathbf{B}_{2}$ & 60.4 & 96.8 & 65.4 & 96.8 \\
$\mathbf{7}$ & $\mathbf{C}_{2}$ & 49.8 & 90.8 & 53.8 & 99.8 \\
$\mathbf{8}$ & $\mathbf{A}_{3}$ & 67.9 & 87.9 & 66.9 & 97.9 \\
$\mathbf{9}$ & $\mathbf{B}_{3}$ & 74.8 & 96.6 & 70.8 & 96.6 \\
\hline
\end{tabular}

\section{Seasonal water applied (Wa)}

Under the conditions of the present study, the seasonal water applied (Wa) consists of the three components; irrigation water (IW), rainfall (R) and contribution of water table (S). Maize as a summer crop growing in months at which there are zero rainfall. Therefore, Wa for maize is the summation of IW and S. As shown in Table (7), number of irrigation applied was 9, 6, 5 during the growing season of maize including the first two irrigations.

Contribution of water table (\%):

Values of contribution of water table to crop evapotranspiration during the two seasons are given in Table (7). Data revealed that by increasing the water applied, less value was obtained. For the maximum water depth $9 \mathrm{~cm}$ each 10 days (treatment $C_{1}$ ) there was no contribution from water table. For the other treatments under the same irrigation intervals of 10 days $B_{1}$ and $A_{1}$ average values of contribution are 3.8 and 5.4 and 3.4, 8.4 for first and second season's respectively. This slight contribution of water table was occurred during about the middle of the season. This finding indicated that by increasing the applied water in the short irrigation interval of 10 days, almost no contribution but the feeding to groundwater table took the same direction with that applied depth. Also, this feeding may be from the neighbouring fields. The reason for the non contribution from water table during other periods may be attributed to the less water consumed by plants at both early and ripening stage (Eid 1994). 
On the other hand, contribution was increased directly by increasing the irrigation intervals. Average values are 8.4, 20.6 and $40.8 \%$ for A1, A2 and A3 treatments respectively. The same direction was observed for treatments $\mathrm{B}$ and $\mathrm{C}$. This contribution was occurred in the middle of the growing season which accompanied with the maximum plant water needs. The reason of the non contribution from water table during other growing periods might be attributed to the less water consumed by plants at both early and ripening stages. So, since there was a feeding to the water table or so called negative contribution to the crop water consumed during mentioned stages, data suggest the rearrange of the irrigation regime through two ways. First by applying less water during those stages to minimize the volume of water percolated to the ground water aquifer and second by increase the irrigation interval but not to degree of the significant decrease in crop production.

It was interest to mention that under treatments which had relatively important values of water table contribution $\left(A_{3}, B_{3}\right.$ and $\left.C_{3}\right)$, the corresponding percentages ranged between $31.2,22.3$ and18.2 \% for first season while it were $40.8,14.6$ and $10.5 \%$ for second season respectively.However, the magnitude of the upward flux into root zone will depend on the soil water potential gradient and soil hydraulic properties and cant be ignored as a source of water contribution to the total crop evapotranspiration.

Table (7): Seasonal irrigation applied (IW), rainfall (R), contribution from water table (S), seasonal water applied (Wa)and contribution of ground water as percentage (\%) for maize in the two seasons

\begin{tabular}{|c|c|c|c|c|c|c|c|c|c|c|c|c|}
\hline & \multicolumn{5}{|c|}{ Season 2009} & & \multicolumn{5}{|c|}{ Season 2010} & \multirow{3}{*}{$\%$} \\
\hline & \multicolumn{2}{|c|}{ IW } & \multirow{2}{*}{$\mathbf{R}$} & \multirow{2}{*}{$\mathbf{S}$} & \multirow{2}{*}{ Wa } & \multirow{2}{*}{$\%$} & \multicolumn{2}{|c|}{ IW } & \multirow{2}{*}{$\mathbf{R}$} & \multirow{2}{*}{$\mathbf{S}$} & \multirow{2}{*}{ Wa } & \\
\hline & No & $\mathrm{Cm}$ & & & & & No & $\mathbf{C m}$ & & & & \\
\hline$\overline{A_{1}}$ & 9 & 52.0 & 0.0 & 3.00 & 55.0 & 5.4 & 9 & 51.0 & 0.0 & 2.98 & 48.0 & 8.4 \\
\hline$A_{2}$ & 6 & 37.0 & 0.0 & 8.44 & 45.44 & 18.5 & 6 & 36.0 & 0.0 & 7.5 & 43 & 20.6 \\
\hline$A_{3}$ & 5 & 32.0 & 0.0 & 14.54 & 46.54 & 31.2 & 5 & 32.0 & 0.0 & 18.67 & 45.67 & 40.8 \\
\hline $\mathrm{B}_{1}$ & 9 & 67.9 & 0.0 & 2.67 & 69.67 & 3.8 & 9 & 67.9 & 0.0 & 2.44 & 70.34 & 3.4 \\
\hline$B_{2}$ & 6 & 46.9 & 0.0 & 7.55 & 54.45 & 13.4 & 6 & 46.9 & 0.0 & 6.98 & 53.88 & 12.9 \\
\hline $\mathrm{B}_{3}$ & 5 & 39.9 & 0.0 & 11.44 & 51.34 & 22.3 & 5 & 39.9 & 0.0 & 7.40 & 50.79 & 14.6 \\
\hline $\mathrm{C}_{1}$ & 9 & 83.9 & 0.0 & 0.00 & 83 & 0.0 & 9 & 83.9 & 0.0 & 0.6 & 84.55 & 00.7 \\
\hline $\mathrm{C}_{2}$ & 6 & 56.9 & 0.0 & 6.43 & 63.33 & 10.1 & 6 & 56.9 & 0.0 & 4.66 & 62.56 & 7.4 \\
\hline $\mathrm{C}_{3}$ & 5 & 45.9 & 0.0 & 10.23 & 56.13 & 18.2 & 5 & 45.9 & 0.0 & 5.87 & 55.77 & 10.5 \\
\hline
\end{tabular}

\section{Grain yield (t/fed.)}

Means of grain yield in ton/fed. of maize as affected by irrigation regime in both seasons of study are shown in Table ( 8). Irrigation regime significantly influenced grain yield per fed. In both seasons, generally, by increasing the water applied from $5 \mathrm{~cm}$ to $7 \mathrm{~cm}$ grain yield increased from 3.18 to 3.5 and 3.120 to 3.470 while irrigation at $9 \mathrm{~cm}$ decreased 3.200 and 3.18 for first and second seasons respectively. Irrigation $9 \mathrm{~cm}$ every 10 days gave the lowest average grain yield in the two seasons $(3.125 \mathrm{t} / \mathrm{fed})$. While the highest grain yield $(3.680,3.580 \mathrm{t} / \mathrm{fed}$.) was obtained from irrigation $7 \mathrm{~cm}$ every 15 days in 2009 and 2010 seasons respectively. 
Eid, S. M. et al.

Table ( 8 ): Effect of irrigation treatment on grain yield ( ton/fed. )of maize during the two seasons 2009 and 2010

\begin{tabular}{|l|c|c|c|c|c|c|c|c|}
\hline & \multicolumn{4}{|c|}{ Season $\mathbf{2 0 0 9}$} & \multicolumn{5}{c|}{ Season 2010 } \\
\hline & $\mathbf{( 5 c m )}$ & $\mathbf{( 7 c m})$ & $\mathbf{( 9 c m )}$ & mean & $\mathbf{( 5 c m )}$ & $\mathbf{( 7 c m})$ & $\mathbf{( 9 c m})$ & mean \\
\hline 10days & $3.300 \mathrm{a}$ & $3.400 \mathrm{~b}$ & $3.100 \mathrm{~b}$ & 3.266 & $3.200 \mathrm{a}$ & $3.500 \mathrm{~b}$ & $3.150 \mathrm{~b}$ & 3.283 \\
15days & $3.213 \mathrm{~b}$ & $3.680 \mathrm{a}$ & $3.280 \mathrm{a}$ & 3.416 & $3.180 \mathrm{a}$ & $3.580 \mathrm{a}$ & $3.180 \mathrm{~b}$ & 3.313 \\
20days & $3.040 \mathrm{c}$ & $3.440 \mathrm{~b}$ & $3.340 \mathrm{a}$ & 3.246 & $3.000 \mathrm{~b}$ & $3.340 \mathrm{c}$ & $3.220 \mathrm{a}$ & 3.186 \\
\hline mean & 3.18 & 3.500 & 3.200 & 3.309 & 3.120 & 3.470 & 3.180 & 3.258 \\
\hline
\end{tabular}

Water productivity (WP):

Water productivity expressed in $\mathrm{kg}$ of grain yield/cm of water consumed is presented in Table (9). The obtained results showed that WP increased as the irrigation water applied decreased. Maize irrigated at $A_{3}$ had the highest value of WP to be $96.88 \mathrm{Kg}$ of grain yield/ $\mathrm{cm}$ of water consumed, while the lowest one was $36.23 \mathrm{Kg}$ of grain yield/ $\mathrm{cm}$ of water consumed, resulted from watering at $\mathrm{C}_{1}$. These findings could be attributed to the highly significant differences among grain maize yield as well as differences between water consumed. The present results are in line with those reported by Ghadiri and Majidian (2003), Abdel Mawly and Zanouny (2005), Yang et al., (2005) ElBably 2007 and El-Atawy (2007), they mentioned that the efficiency of water use decreased as the soil moisture was maintained high by frequent irrigation.

Productivity of irrigation water (PIW):

Mean values of PIW were affected by irrigation interval and depths of irrigation are shown in Table (9). Results indicated that the highest values of PIW are 91.89 and $80.46 \mathrm{~kg} / \mathrm{cm}$ recorded from the irrigation at $5 \mathrm{~cm}$ of depth $\left(A_{2}\right)$ and irrigation every 15 days in the first and second seasons respectively whereas the lowest ones are 36.23 and $35.48 \mathrm{~kg} / \mathrm{cm}$ were obtained from irrigation at $9 \mathrm{~cm}$ depth $\left(\mathrm{C}_{3}\right)$ and irrigation every 20 days. These results could be attributed to the significant differences among maize grain yield, evapotranspiration and water applied values.

Table (9): Average values of grain yield (kg/fed.), consumptive use (Cu) $\mathrm{cm} / \mathrm{fed}$. Water applied (Wa) $\mathrm{cm} / \mathrm{fed}$. Crop water productivity (WP) $\mathrm{kg} / \mathrm{cm}$ and productivity of irrigation water (PIW) $\mathrm{kg} / \mathrm{cm}$ (average of two seasons 2009 and 2010 ).

\begin{tabular}{|c|c|c|c|c|c|c|c|c|c|c|c|}
\hline \multirow[b]{2}{*}{ 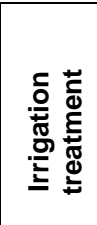 } & \multirow[b]{2}{*}{ 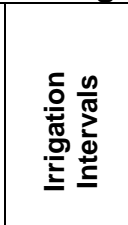 } & \multicolumn{5}{|c|}{ Season 2009} & \multicolumn{5}{|c|}{ Season 2010} \\
\hline & & 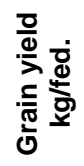 & 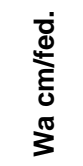 & 己 & 帘 & $3 \frac{g}{0}$ & 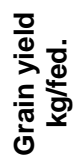 & 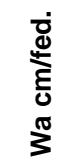 & ن & 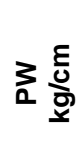 & 文施 \\
\hline \multirow[t]{3}{*}{$\mathrm{A}(5 \mathrm{~cm})$} & 1(10days) & 3200 & 55.00 & 52.0 & 61.54 & 58.18 & 320 & 48.0 & 53.0 & 60.38 & 66.67 \\
\hline & $2(15$ & 3400 & 48.44 & 37.0 & 91.89 & 70 & 35 & 43.5 & 38.0 & 92.11 & 80. \\
\hline & $3(20$ & 3100 & 46.54 & 32.0 & 96.88 & 66.61 & 318 & 45.6 & 33.0 & 96.36 & 69.63 \\
\hline \multirow[t]{3}{*}{$B(7 \mathrm{~cm})$} & 1(10days) & 3213 & 69.67 & 67.9 & 47.32 & 46.12 & 318 & 70.3 & 68.9 & 46.15 & 45.21 \\
\hline & $2(15 d$ & 3600 & 54.45 & 46.9 & 76.76 & 66.12 & 358 & 53.8 & 47.9 & 74.74 & 66.44 \\
\hline & & 3280 & 51.34 & 39.9 & 82.21 & 63.89 & 318 & 50.7 & 40.9 & 77.75 & 62.61 \\
\hline \multirow[t]{3}{*}{$\mathbf{C}(9 \mathrm{~cm})$} & $1(10$ & 3040 & 83.90 & 83.9 & 36.23 & 36.23 & 3000 & 84.5 & 84.9 & 35.34 & 35.48 \\
\hline & & 3440 & 63.33 & 56.9 & 60.46 & 54.32 & 3340 & 62.5 & 57.9 & 57.69 & 53.39 \\
\hline & 3(20days) & 3400 & 56.13 & 45.9 & 74.07 & 60.57 & 3220 & 55.7 & 46.9 & 68.66 & 57.74 \\
\hline
\end{tabular}




\section{CONCLUSION}

It could be concluded that with increasing irrigation intervals, the contribution increased from 8.4 to 20.6 to $40.8 \%$ for $A_{1}, A_{2}$ and $A_{3}$ i.e 10,15 , and 20 days treatments respectively. Under the same irrigation interval of 20 days which accompanied with increase in water depth applied from 5 to 7 to 9 $\mathrm{cm}$ i.e. treatments $A_{3}, B_{3}$ and $C_{3}$ the contribution of water table decreased from 40.8 to 14.6 to $10.5 \%$ respectively.

\section{REFERENCES}

Abdel-Mawly, S.E. and I. Zanouny (2005). Irrigation and fertilization management for maximizing crop-water Effeciencies of Maize. Minia J. Agric. Res. And Develop., 25 (1):125-146

Ahmed, N. Ch. (1992). Mechanisms for Coping with Salinity and Water Logging. IWMI Internal Report.

Ali, M. H.; M. R. Hoque; A. A. Hassan and A. Khair (2007). Effects of deficit irrigation on yield, water productivity, and economic returns of wheat. Agricultural Water Management 92 (3): 151-161.

Ayars, J.E., Christen, E.W., Soppe, R.W., and Mayers, W.S., (2006).The resource potential of in situ shallow ground water use in irrigated agriculture: a review. Irrig. Sci. 24 (3),47-160.

Ayars, J.E., Hutmacher, R.B., Schoneman, R.A., Vail, S.S., and Pflaum,T.,(1993). Long term use of saline water for irrigation. Irrig.Sci. 14, 27-34.

Ayars, J.E., and Schoneman, R.A., (1986). Use of saline water from a shallow water table by cotton. Trans. ASAE 29, 1674-1678.

Eid, S.M.I. (1994): Some water applications and yield of sugar beet and sunflower crops as influenced by frequency and amounts of irrigation water in Northern Delta . M.Sc. thesis, Fac. Agric Tanta Univ.

El-Atawy, Gh. Sh. (2007). Irrigation and fertilization management under the conditions of Kafr El-Sheikh Governorate soil. Ph.D. Thesis, Soil Dept. Fac. of Agric., Mansoura Univ., Egypt

El-Bably A. Z. (2007). Irrigation scheduling of some maize cultivars using class A pan evaporation in north delta Egypt. Bull. Fac., Agric., Cairo Univ., 58 (3): 222-232.

Ghadiri, H. and Majidian, M. (2003). Effect of different nitrogen fertilizer levels and moisture stress during milky and dough stages on grain yield, yield components and water use efficiency of corn (Zea mays L.). Journal of Science and Technology of Agriculture and Natural resources. 7(2): 103-113.

Giriapa, S. (1983). Water use efficiency in agriculture. Oxford-IBH Publishing Co., New Delhi, 6-9.

Gomez, K. A. and A.Gomez (1984). Statistical procedures for agricultural research. 1st ed. John Wiley Sons, New Yourk.

Hansen, U. W.; O. W. Israelsen and Q. E. Stringharm (1979). Irrigation Principles and Practices. 4th (ed.). John Willey and Sons

Hutmacher, R.B., Ayars, J.E., Vail, S.S., Bravo, A.D., Dettinger, D., and Schoneman, R.A., (1996). Uptake of shallow groundwater by cotton: growth stage, groundwater salinity effects in column lysimeters. Agric.Water Manage.31, 205-223.

Kahlown, M.A., Ashraf, M., and Zia-ul-Haq, (2005). Effect of shallow groundwater table on crop water requirements and crop yields. Agric. Water Manage. 76 (1), 24-35. 


\section{Eid, S. M. et al.}

King, C.A., Schwamberger, E.C., Wallace, N., Smith, D.S., Meyer, W.S., and Thorburn, P.J., (1995). Water use, plant development and capillary upflow from saline water tables in four soils for irrigated maize. CSIRO Technical Memorandum, 95.8.

Pratharpar, S.A., and Qureshi, A.S., (1998). Modelling the effects of deficit irrigation on soil salinity, depth to water table and transpiration in semiarid zones with monsoonal rains. Water Resour. Dev. 15, 141-159.

Rhoades, J.D., Bingham, F.T., Letey, J., Hoffman, G.J., Dedrick,A.R., Pinter, P.J., and Replogle, J.A., (1989). Use of saline drainage water for irrigation: imperial valley study. Agric. Water Manag. 16, 25-36.

Soppe, R.W.O., and Ayars, J.E., (2003). Characterizing ground water use by safflower using weighing lysimeters. Agric.Water Manage. 60, 59-71.

Waller, R.A. and D.B.Duncan. (1979). Symmetric multiple Comparison Problem. Amer. Stat.Assoc. Jour.December, 1485-1503.

Yang, T.; Liang, Z.S.; Xue, J. and Kang, S. (2005). Diversity of water use efficiency in various maize varieties. Transaction of the Chinese Society of Agricultural Engineering. 21(10): 21-25.

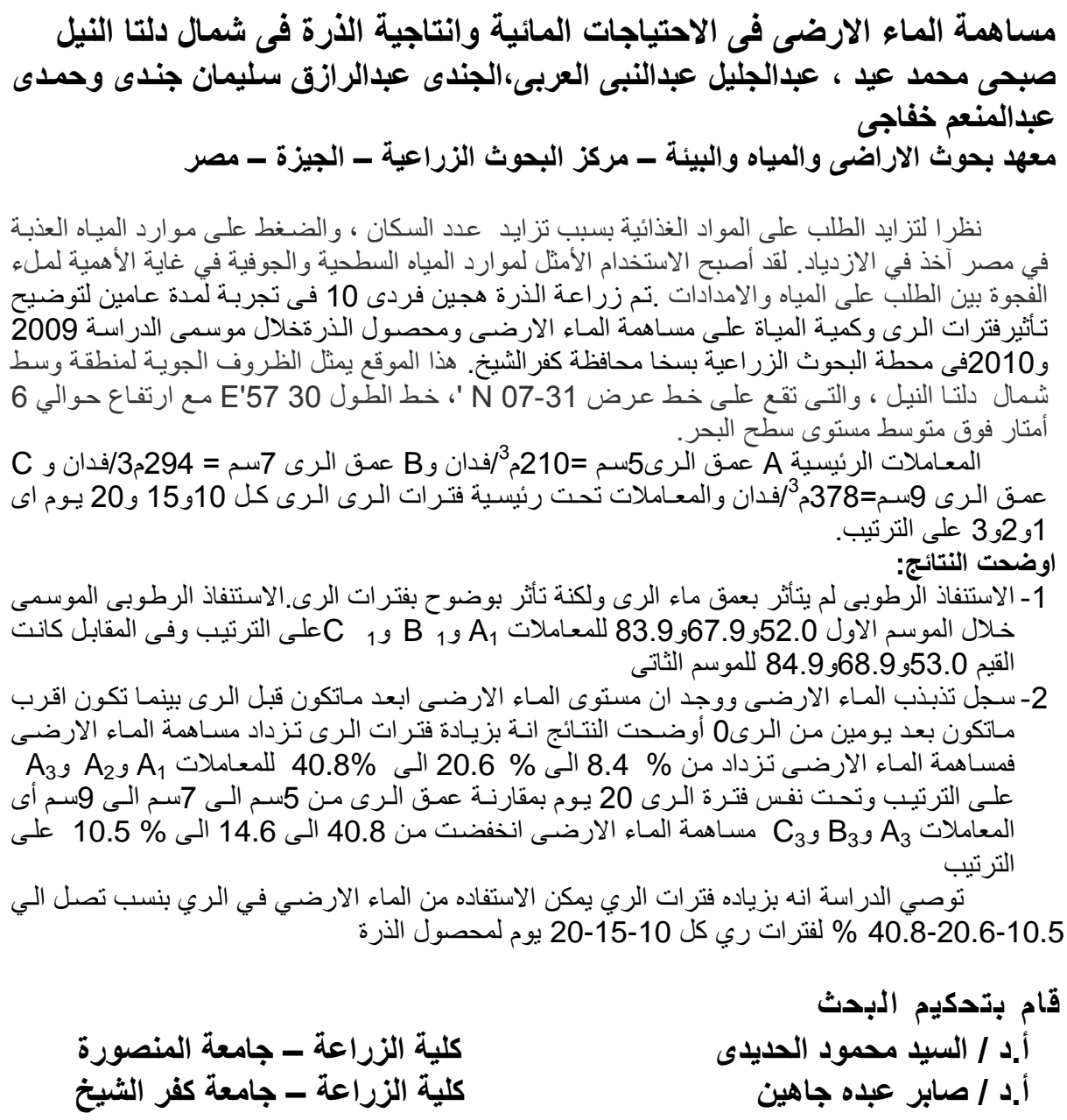


J. Soil Sci. and Agric. Eng., Mansoura Univ., Vol. 3 (2), February, 2012 